\title{
ACCOUNTABILITY E INDEPENDÊNCIA JUDICIAIS: UMA ANÁLISE DA COMPETÊNCIA DO CONSELHO NACIONAL DE JUSTIÇA(CNJ)
}

\author{
Fabrício Ricardo de Limas Tomio
}

\author{
Ilton Norberto Robl Filho
}

\begin{abstract}
RESUMO
A Constituição de 1988 atribuiu substancial independência ao poder judiciário. Há garantias institucionais (autonomia financeira/administrativa e autogoverno), garantias funcionais (vitaliciedade, irredutibilidade salarial e inamovibilidade) e proteção à independência. De outro lado, apesar da substancial independência judicial, observavam-se antes da EC 45/2004 (reforma do judiciário e criação do CNJ) profundos déficits de accountability vertical judicial (possibilidade de os cidadãos controlarem e influenciarem as ações do judiciário) e accountability horizontal judicial (controle de juízes e tribunais por outros órgãos judiciários). $O$ artigo analisa, a partir da definição e diferenciação do conceito de accountability judicial e do arranjo institucional posterior à EC 45/2004, como as competências do CNJ podem ser exercidas para ampliar os mecanismos de accountabilities e de controle do judiciário sem restringir a independência decisional judicial.
\end{abstract}

PALAVRAS-CHAVE: accountability judicial; reforma do poder Judiciário; CNJ; instituições políticas.

\section{INTRODUÇÃO 1}

A Constituição Brasileira de 1988 atribuiu substancial independência ao poder Judiciário. Há garantias institucionais (autonomia financeira-administrativa e autogoverno), garantias funcionais (vitaliciedade, irredutibilidade salarial e inamovibilidade) e proteção à imparcialidade. Por outro lado, antes da reforma do poder Judiciário (EC 45/2004) e da conseqüente instituição do Conselho Nacional de Justiça (CNJ), facilmente eram observados profundos déficits de accountability no Judiciário. O problema central deste artigo envolve responder as seguintes questões, decorrentes da reforma constitucional: $(i)$ as competências do CNJ geraram novos controles (accountability) e redefiniram a independência do poder Judiciário brasileiro? (ii) Como resolver a relação institucional (constitucional e teórica), de difícil e delicada conciliação, entre independência do poder Judiciário (autonomia administrativa e decisional) e accountability (controle externo e interno) das atividades e dos tribunais e membros do poder Judiciário?

\footnotetext{
1 Uma versão preliminar do artigo foi apresentada no $8^{\mathrm{a}}$ Encontro ABCP (Gramado, 1-4/agosto/2012, AT Política, Direito e Judiciário). Agradecemos aos debatedores os comentários. Possíveis imprecisões são de responsabilidade dos autores. O estudo foi desenvolvido no Núcleo de Pesquisa "DIRPOL-Direito e Política" (PPGD/UFPR) com o financiamento do CNJ Acadêmico/Capes (2010) e do CNPq/ Capes (Edital 07/2011). Agradecemos também aos pareceristas da Revista de Sociologia e Política.
}

$\mathrm{O}$ argumento básico, decorrente da análise do desenho institucional do $\mathrm{CNJ}$, é que a reforma preencheu algumas lacunas de accountabilities presentes do arranjo constitucional de 1988 por meio de mecanismos de accountabilities horizontal e vertical não eleitoral do poder Judiciário. É nítido o desenho institucional do CNJ como instrumento de accountability interna do Judiciário. Por outro lado, algo não tão claro é a participação do CNJ em uma rede de accountability social (vertical não eleitoral) do Judiciário. Além disso, para uma análise mais precisa da função e desenho institucional do CNJ, argumentamos que é teoricamente insuficiente utilizar apenas os conceitos de accountabilities vertical e horizontal no estudo do controle do poder Judiciário. Desse modo, propomos a utilização dos conceitos de accountabilities judiciais (decisional, comportamental, legal e institucional), relacionando-os com a independência judicial (decisional, comportamental e institucional) e com as categorias clássicas de accountability.

Por fim, para a construção da exposição, o artigo foi estruturado em três partes. As duas primeiras abordam as diversas modalidades de accountability, a estrutura conceitual da accountability e as formas de accountabilities no estudo da independência e do controle do poder Judiciário. A terceira analisa a accountability no poder Judiciário brasileiro, as significativas prerrogativas de independência judiciais e os efeitos institucionais da reforma (EC 45/2004), bem como a função, composição e competência do CNJ decorrentes desses efeitos. 


\section{AS MODALIDADES DE ACCOUNTABILITY}

Em uma definição preliminar, accountability significa a necessidade de uma pessoa ou instituição que recebeu uma atribuição ou delegação de poder prestar informações e justificações sobre suas ações e seus resultados, podendo ser sancionada política, pública, institucional e/ou juridicamente por suas atividades. $\mathrm{Na}$ accountability vertical típica (eleitoral), por meio da eleição, os cidadãos sancionam os agentes estatais em virtude da avaliação de seus atos e pelos resultados promovidos por representantes e autoridades eleitas. Em uma variação desse tipo de accountability vertical (social), as organizações da sociedade e a imprensa sancionam (por meio de denúncias e exposição pública) agentes estatais eleitos ou não eleitos. Por sua vez, accountability horizontal (institucional) ocorre quando agentes estatais (individuais ou coletivos) podem requerer informações e justificações de outros agentes estatais, além de poder sancioná-los.

No exercício do poder Judiciário, dotado de garantias extensas de independência e sem mecanismos de seleção por eleições, como o previsto constitucionalmente no Brasil, as formas de accountability judiciais encontram-se principalmente na esfera institucional, podendo ser diferenciadas como: (i) "accountability judicial 'decisional", que significa a possibilidade de requerer informações e justificações dos magistrados pelas decisões judiciais, além de aplicar uma sanção por essas decisões; (ii) "accountability judicial comportamental", que significa receber informações e justificações sobre o comportamento dos magistrados (honestidade, integridade, produtividade, entre outros), também sendo autorizada a atribuição de sanção; (iii) "accountability judicial institucional", que diz respeito às informações e às justificações sobre ações institucionais não jurisdicionais (administração, orçamento e relações com outros poderes), assim como a sanção pela realização de processos institucionais inadequados; (iv) por fim, "accountability judicial legal" significa o fornecimento de informações e justificações sob o cumprimento da lei, além da sanção no caso de sua violação.

\section{QUADRO 1 - MODALIDADES DE ACCOUNTABILITY (GERAL E JUDICIAL)}

\begin{tabular}{|c|c|c|c|}
\hline $\begin{array}{l}\text { Accountability } \\
\text { vertical } \\
\text { (eleitoral) }\end{array}$ & $\begin{array}{l}\text { Cidadãos sancionam por meio } \\
\text { da eleição os representantes e } \\
\text { autoridades eleitas (pelos atos e } \\
\text { resultados promovidos). }\end{array}$ & & \\
\hline $\begin{array}{l}\text { Accountability } \\
\text { vertical (social) }\end{array}$ & $\begin{array}{l}\text { Sociedade organizada e } \\
\text { imprensa sancionam por meio } \\
\text { de denúncia e exposição pública } \\
\text { os agentes estatais eleitos ou } \\
\text { não eleitos. }\end{array}$ & $\begin{array}{l}\text { Accountability } \\
\text { judicial } \\
\text { decisional }\end{array}$ & $\begin{array}{l}\text { Possibilidade de requerer } \\
\text { informações ou justificações dos } \\
\text { magistrados pelas decisões } \\
\text { judiciais, além de aplicar uma } \\
\text { sanção por essas decisões. }\end{array}$ \\
\hline \multirow[t]{3}{*}{$\begin{array}{l}\text { Accountability } \\
\text { horizontal } \\
\text { (institucional) }\end{array}$} & \multirow[t]{3}{*}{$\begin{array}{l}\text { Agentes estatais (individuais ou } \\
\text { coletivos) podem requerer } \\
\text { informações e justificações de } \\
\text { outros agentes estatais, além de } \\
\text { poder sancioná-los. }\end{array}$} & $\begin{array}{l}\text { Accountability } \\
\text { judicial } \\
\text { comporta- } \\
\text { mental }\end{array}$ & $\begin{array}{l}\text { Receber informações ou } \\
\text { justificações sobre o } \\
\text { comportamento dos } \\
\text { magistrados (honestidade, } \\
\text { produtividade etc.) sendo } \\
\text { autorizada a sanção prevista. }\end{array}$ \\
\hline & & $\begin{array}{l}\text { Accountability } \\
\text { judicial } \\
\text { institucional }\end{array}$ & $\begin{array}{l}\text { Receber informações ou } \\
\text { justificações sobre ações não } \\
\text { jurisdicionais (administrativas, } \\
\text { em especial), com a sanção } \\
\text { pela realização de atos } \\
\text { inadequados. }\end{array}$ \\
\hline & & $\begin{array}{l}\text { Accountability } \\
\text { judicial legal }\end{array}$ & $\begin{array}{l}\text { Fornecimento de informações } \\
\text { ou justificações sobre o } \\
\text { cumprimento da lei, além da } \\
\text { sanção no caso de sua violação. }\end{array}$ \\
\hline
\end{tabular}

FONTE: Os autores.

Como expressado acima, ou com variações significativas, a noção de accountability tem sido usado em estudos de Ciência Política, Administração Pública, Economia e Direito para expressar diversas modalidades de controle e de relações entre mandante e agente (políticos e/ou institucionais) $)^{2}$. A compreensão do termo

2 A utilização do termo accountability é relativamente recente, entretanto, as relações de accountability podem ser encontradas na teoria sobre o Estado de Direito em Hobbes, Locke, 
accountability pressupõe a apreensão das categorias mandante (mandante) e agent (agente ou mandatário), assim como da estrutura analítica da accountability: answerability (necessidade de dar respostas) e enforcement (coação). Dessa forma, accountability é uma relação que se estabelece entre mandante e agente ou entre os agentes entre $\mathrm{si}^{3}$. No âmbito dos estudos das instituições democráticas, a grande questão é como construir um arranjo institucional que estimule os atores individuais (agentes) a um comportamento mais benéfico possível à coletividade ${ }^{4}$. $\mathrm{Ou}$, como expressa Przeworski, o objetivo "é construir instituições que dêem poder ao aparelho do Estado para fazer o que deve fazer e o impeçam de fazer o que não deve fazer" (PRZEWORSKI, 2006, p. 39).

As relações democráticas podem ser analisadas por meio das categorias mandante-agente. Entretanto, os magistrados, como os burocratas, são agentes que possuem peculiares relações com o principal: normalmente, não são eleitos ${ }^{5}$. No que se refere ao poder Judiciário, como regra, os magistrados são selecionados por concurso de provas e títulos ou por indicação política ${ }^{6}$. Para que as relações entre mandante e agente funcionem adequadamente, há o estabelecimento de um processo de responsabilização do agente por meio das suas ações e omissões. Essa responsabilização pode ser político-eleitoral, legalinstitucional ou social. Esses processos de responsabilização pressupõem a existência de informações. Na relação mandante-agente, o mandante, a partir das informações que possui e das que pode ter acesso, analisa as ações dos agentes e

Montesquieu, Constant, Federalistas etc., conforme O'Donnell (1998, p. 27-40), Mota (2006, p. 62-79), Trebilcock e Daniels (2008, p. 57-66), Romêo (2009, p. 171-174). Campos (1990) afirma, inclusive, que não haveria instituições capazes de exercer o accountability no Brasil. Pinho e Sacramento (2009, p. 1344) advertem que Campos escreve antes da Constituição Federal de 1988, que estabeleceu inúmeros mecanismos de accountability.

3 A perspectiva mandante-agente é apresentada por North (1995), Przeworski (2006) e O’Donnell (2009).

4 Segundo O’Donnell (1998), Offe (1999), Przeworski (1999; 2006), Arato (2002), Peruzzotti e Smulovitz (2002), Miguel (2005) e Rose-Ackerman (2005).

5 Sobre a relação mandante-agente nas burocracias ver Przeworski (2006, p. 52-59).

6 Observa-se, contemporaneamente, a valorização da escolha política do magistrado a partir do seu mérito. Mesmo nos Estados Unidos, onde alguns estados escolhem seus magistrados por meio de eleições, segundo Garoupa e Ginsburg (2008, p. 13-14) em 33 estados funcionam Merit Plan Systems (conselhos compostos por juízes, advogados e cidadãos que nomeiam juízes estaduais ou elaboram lista para posterior escolha e nomeação pelo governador). estabelece prêmios ou sanções. Assim, há o estímulo para o agente atuar no interesse do mandante (PRZEWORSKI, 2006, p. 45). Como há mecanismos de sanção do mandante sobre o agente, este não buscaria atuar exclusivamente em interesse particular, pois sabe que sua ação poderia ser sancionada pelo mandante e por outros agentes que possuem poder de fiscalização sobre ele.

Para que exista uma relação de accountability forte, o agente accountable: $(i)$ possui o dever de apresentar informações sobre as suas ações ao mandante e a outros agentes com competência para exigir a informação do agente accountable; (ii) este é obrigado a justificar suas atitudes e ações e (iii) pode ser sancionado ou premiado pelo mandante e pelos agentes com competência para tanto. $\mathrm{O}$ aspecto da coação é importante para estabelecer uma relação de accountability forte ou plena. Não basta os agentes apresentarem e justificarem suas ações, devem também poder ser sancionados por não concretizar os interesses do mandante e por descumprir normas legais e constitucionais. A ausência da sanção constrói uma forma fraca de accountability ${ }^{7}$.

Como dito anteriormente, as relações de accountability vertical acontecem entre povo e Estado, já as relações de accountability horizontal entre agentes estatais ${ }^{8}$. Podemos recolocar essa relação na perspectiva mandante-agente. $\mathrm{Na}$ accountability vertical, há típicas relações entre mandante-agente: eleitor ou grupos da sociedade civil (mandante) e representante eleito ou não

7 Segundo Schedler (1999, p. 17), sanções softs, como destruição da reputação de uma personalidade pública e demissão de um ministro em virtude da conveniência política, nos casos de violações às leis, são relevantes, porém insuficientes. Entretanto, há um tipo de accountability fraco apoiado na literatura, como as comissões de verdade apenas dotadas de poder sancionatório fraco (exposição pública). Essa forma de accountability é apoiada, por exemplo, por Rose-Ackerman (2005, p. 14). Além disso, segundo Shedler (1999, p. 20), não existe accountability quando uma pessoa, grupo ou órgão possui pleno controle sobre outra pessoa. Essa é a grande razão para a accountability ser exigida de agentes, pois, por mais que existam sanções, ele pode descumprir os comandos postos na legislação e os interesses do mandante.

8 O’Donnell (1998, p. 40) define accountability horizontal como "a existência de agências estatais que têm o direito e o poder legal e que estão de fato dispostas e capacitadas para realizar ações, que vão desde a supervisão de rotina a sanções legais ou até o impeachment contra ações ou omissões de outros agentes e agências de Estado que possam ser qualificadas como delituosas". Há, pelo menos, uma limitação nessa definição. A accountability horizontal não acontece apenas quando um agente sanciona uma conduta delituosa. Também há accountability horizontal quando um agente pode restringir uma ação tomada por outro agente por razões como a não concordância política. É comum indicar o checks and balances como uma rede importante de accountability horizontal, como em Diamond, 
eleito (agente). Por sua vez, na accountability horizontal observa-se que existe um agente accountable que deve prestar informações e justificações a outro agente competente, podendo este aplicar sanções. Em ambos os casos, conforme o arranjo institucional, diferentes mecanismos permitem variáveis graus de responsabilização dos agentes estatais ${ }^{9}$ ou resolução dos problemas informacionais que envolvem a relação mandante-agente ${ }^{10}$.

Novas modalidades de controle encontram-se, por exemplo, em diferentes relações entre accountability vertical e horizontal. A possibilidade de cidadãos apresentarem reclamações às ouvidorias judiciais mescla de maneira interessante o aspecto vertical (possibilidade de apresentação de reclamações e pedidos de informações pelos cidadãos) e o aspecto horizontal (capacidade de o ombudsman obrigar o magistrado a prestar informação).

Um modelo pautado na accountability eleitoral pura desconsidera substancialmente os papéis da accountability horizontal e do constitucionalismo, estruturado na separação de poderes, na proteção aos direitos fundamentais e no pluralismo político

Plattner e Schedler (1999, p. 3) e Romêo (2009, p. 171-172). Um exemplo torna essa questão mais clara. O presidente pode vetar uma lei aprovada pelo parlamento não em razão da prática de um delito, mas em virtude da não concordância política.

9 Segundo Przeworski: “A verdade é que, nos últimos 200 anos, pensamos pouco sobre o desenho institucional da democracia. Desde a grande explosão do pensamento institucional, quando se inventaram as instituições democráticas atuais - e, sim, elas foram inventadas - praticamente não se viu mais criatividade institucional [...] as últimas grandes invenções políticas foram a descoberta da representação proporcional, nos anos de 1860, e dos partidos de massa, nos anos de 1890 [...]. Há, portanto, muito espaço para a criatividade institucional" (PRZEWORSKI, 2006, p. 68-69). Para dotar os cidadãos de maiores instrumentos de controle sobre os agentes políticos e exercer a accountability eleitoral, por exemplo, autoridades políticas importantes (ministros e outras autoridades) deveriam ser eleitas (MANIN, PRZEWORSKI \& STOKES, 2006, p. 134). Nesse sentido, parece razoável a proposição de Miguel (2005, p. 29), de que os problemas para a efetivação da accountability não podem gerar propostas de um modelo mínimo, como por exemplo, a proposta de relacionar a accountability somente com controle sobre a corrupção.

10 As instituições democráticas que auxiliam o cidadão no acesso e na análise de informações importantes para accountability eleitoral seriam: (i) um conselho autônomo que assegure a transparência do orçamento e das fontes de campanha, sendo esse órgão dotado de poder para promover investigações; (ii) um órgão auditor, com independência do Estado, para fiscalizar os agentes estatais; (iii) fontes independentes de informações estatísticas sobre a economia e (iv) espaço adequado para que a oposição vigie o Estado e as mídias estatais (MANIN, PRZEWORSKI \& STOKES, 2006, p. 133).
(DIAMOND, PLATTNER \& SCHEDLER, 1999, p. 2) ${ }^{11}$. Por meio da concepção de governo responsável e pela accountability horizontal, adota-se a idéia e a prática de que um governo dividido é necessariamente limitado. Para exercer suas funções, um poder ou autoridade necessita da ação e da cooperação de outro poder ou órgão, buscando coibir a existência de unchecked power (poder sem controle) (PREZEWORSKI, 1999, p. 328-329) ${ }^{12}$.

A regra, na democracia, é a atribuição de poder por meio das eleições. Por outro lado, muitas funções e serviços públicos são delegados para burocracias não eleitas. Em virtude disso, no processo de desenho institucional, alguns cuidados devem ser tomados para a fiscalização dos agentes não eleitos ser adequada. Primeiro, as instituições precisam ser desenhadas para receber informações dos cidadãos e os agentes devem ser dotados de competência para fiscalizar e sancionar a partir das informações obtidas. Mecanismos de participação dos cidadãos têm sido apontados como elementos que podem auxiliar no controle dos agentes estatais e dos burocratas. Entre os mecanismos específicos de participação popular, encontram-se a participação dos cidadãos em conselhos específicos e o recebimento de reclamações e sugestões populares sobre a qualidade e a eficácia dos sistemas públicos (PRZEWORSKI, 2006, p. 58).

Segunda questão: outros meios de controle são definidos como novos atores de accountability horizontal. Segundo Diamond, Plattner e Schedler (1999, p. 3), esses são novos agentes que podem demandar informações, analisar justificações e sancionar legal e politicamente outros agentes. Ganharam notoriedade, por exemplo, as ações de comissões e tribunais de direitos humanos, ombudsman, ouvidorias, agências de auditorias, controladorias etc. Esses atores de accountability horizontal tornam mais complexa a rede anterior de controles.

\footnotetext{
11 Sobre a relação do constitucionalismo com as accountabilities horizontal e vertical, ver Arato (2002). Além disto, o constitucionalismo estabelece uma série de prescrições sobre condutas e procedimentos que precisam ser seguidos pelos agentes estatais. Sem agentes para impor os sistemas legal e constitucional inexiste accountability (PERUZZOTTI \& SMULOVITZ, 2002, p. 26).

12 Para Przeworski (1999, p. 331), os agentes estatais não violariam a lei pelo temor em receber sanções políticas e legais de outros agentes estatais (accountability horizontal) ou dos eleitores (accountability vertical eleitoral). No que diz respeito à estrutura de accountability horizontal, revela-se importante a existência de controles recíprocos entre os agentes, a qual pode ser pensada por meio da seguinte concepção geral: agente A segue a lei por temor da sanção do agente B. Este sanciona aquele por medo da possível sanção de $\mathrm{C}$, sendo $\mathrm{C}$ fiscalizado por A.
} 
A reflexão sobre a accountability horizontal também estimulou a discussão sobre outra forma de accountability: a social. Essa modalidade acontece na relação de parte da sociedade civil sobre os agentes estatais eleitos ou não eleitos, sendo um tipo de accountability vertical. Dessa forma, uma parcela do povo (mandante) exige informações e justificações dos agentes, porém a sanção ou o prêmio não acontece de maneira direta pelas eleições ${ }^{13}$. Com o intuito de tornar os agentes (eleitos ou não) mais responsivos e de auxiliar na construção e aprofundamento das instituições democráticas, Peruzzotti e Smulovitz (2002, p. 23-24) afirmam que a sociedade civil e a imprensa gradativamente desempenham uma forma de accountability social e sancionam os agentes por meio da exposição pública. Nesse processo de exposição pública, os agentes dotados de competência de exigir accountability horizontal seriam compelidos a exercer sua função sobre os agentes estatais ${ }^{14}$.

\section{FORMAS DE ACCOUNTABILITIES, INDEPEN- DÊNCIA E CONTROLE DO PODER JUDI- CIÁRIO}

A discussão desta seção aborda a independência dos agentes responsáveis por aplicar as sanções legais e políticas na accountability horizontal. Trata-se de uma modalidade específica de independência: agentes estatais que não são sujeitos ao controle partidário, sendo dotados de vitaliciedade ou mandatos fixos (PRZEWORSKI, 1999, p. 334). O principal tipo de agente de accountability horizontal independente é o poder Judiciário. Essa configuração institucional do Judiciário traz a seguinte questão: quem guarda e como se guarda o guardião? ${ }^{15}$ Já na década de 1990 , O’Donnell (1998, p. 49) e Przeworski (1999, p. 330) apontaram a ausência de accountability do poder Judiciário brasileiro. No Estado Democrático de Direito, a discussão sobre a accountability judicial relaciona-se, necessariamente, com a independência

\footnotetext{
13 Essa forma de accountability foi apresentada como específica por Peruzzotti e Smulovitz (2002).

14 Há mecanismos que permitem aos cidadãos, informados por instrumentos de accountability social, diretamente provocarem os agentes de accountability horizontal. No Brasil, o exemplo é a ação popular que permite aos cidadãos exigir a anulação de ato lesivo ao patrimônio público, nos termos do art. $5^{\circ}$, LXXIII da Constituição Federal. Sobre a ação popular e sua relação com a accountability, ver Mota (2006, p. 144172).
}

15 Esse é o tema da accountability judicial, que se concentra na análise do: (i) choque do poder Judiciário com agentes eleitos e sujeitos à accountability vertical; (ii) crítica de que juízes e tribunais não são analisados por meios tradicionais de accountability e não estabelecem mecanismos suficientes de accountability interna; (iii) existência de forte independência judicial. As questões sobre accountability judicial inserem-se no âmbito de discussão designado por Schedler (1999, p. 25) como problemas de segunda ordem de accountability. Nesse campo, busca-se responder ao seguinte dilema: como criar instituições com funções de accountability horizontal que sejam elas mesmas accountable?

A busca por solução desse problema encontra-se no contexto de criação de agentes de accountability especializados, sendo compostos por membros muitas vezes não eleitos e dotados de independência. O senso comum teórico dos juristas parte do pressuposto de que esses agentes agem com "sinceridade" e de maneira proba no cumprimento das suas funções. Contudo, investigações relatam que os agentes de accountability horizontal não eleitos e independentes no cumprimento da sua missão de análise das informações, justificações e aplicações de sanções podem atuar de maneira ineficiente e com abuso de autoridade, além de usurpar competência de outros agentes estatais eleitos ou não (SCHEDLER, 1999, p. 26).

Há, pelo menos, três arranjos institucionais descritos para lidar com a ausência de accountability sobre agentes não eleitos e independentes: (i) criar um mecanismo de eleição para esses agentes; (ii) desenhar relações institucionais dos agentes estatais entre si para que se estabeleçam interações vedando a existência de unchecked power/agent e (iii) desenvolvimento de relações internas ou externas de accountability dentro de uma agência ou poder ${ }^{16}$. Entretanto, para pensar a relação entre independência e a accountability judicial é relevante diferenciar essas características do poder Judiciário.

sem a devida accountability, podendo os juízes atuarem de maneira não democrática e para além dos seus limites e competências; (iv) essa modalidade de independência significa financiamento público, porém accountable para si mesmo, sendo possível o poder Judiciário tornar-se unchecked power; $(v)$ o próprio poder Judiciário e as agências responsáveis pela análise das informações judiciais agem de maneira que dificulta o acesso da sociedade civil às informações sobre o poder Judiciário. Sobre os três primeiros itens, ver Diamond, Plattner e Schedler (1999, p. 3); sobre as questões quatro e cinco, ver Przeworski (1999, p. 334-335).

16 Esses três arranjos institucionais estão presentes no sistema poder Judiciário norte-americano. Em trinta e nove estadosmembros ocorrem eleições competitivas ou de retenção/ manutenção para a composição do poder Judiciário estadual (accountabilityvertical eleitoral). Segundo, a magistratura federal de todos os níveis hierárquicos é nomeada a partir da indicação do presidente da república e da sabatina do senado federal. Por fim, o Congresso é competente para criar e extinguir tribunais federais, aprovar o orçamento do poder Judiciário federal, aplicar o impeachment em magistrados que não seguiram a cláusula de bom comportamento e estabelecer leis processuais. 
Primeiro, a accountability judicial decisional deve ser desenhada com muito cuidado para não afrontar o conceito de independência judicial decisional (BRODY, 2009 , p. 9). Essa forma de independência afirma que o magistrado deve analisar os casos trazidos à sua jurisdição de acordo com a livre interpretação dos fatos, das leis e da constituição (FEREJOHN, 1999, p. 353). Assim, o juiz não pode ser sancionado por tribunais superiores, pelo povo ou por membros do poder Executivo e do poder Legislativo, pelas decisões que tomou em conformidade com a independência judicial decisional. Desse modo, a accountability judicial decisional impõe ao magistrado que, na sentença, apresente as principais informações sobre o caso e justifique por meio dos fatos, das leis e da constituição a sua decisão judicial. Essa forma de accountability também estabelece o sistema de recursos judiciais ${ }^{17}$.

A possibilidade de afrontar a independência judicial decisional pelo julgamento não estar de acordo com interesses ou perspectivas de parte da população é perigosa, pois pode essa violação ser utilizada por grupos sociais, econômicos e políticos fortes para retirar direitos constitucionais e legais de grupos fracos ou minorias (BRODY, 2008, p. 9). Um dos problemas gerados pelas eleições judiciais em estados-membros da federação norte-americana está em, por meio da accountability eleitoral, implantar-se uma forma de accountability judicial decisional que afronta a independência judicial decisional ${ }^{18}$. O problema em afrontar a independência judicial é que se trata de um

17 Em caso de equívocos ou de não concordância de uma das partes na interpretação dos fatos, da lei e da constituição, existe a faculdade de apresentação de recurso para a mesma instância ou para um tribunal superior. $\mathrm{O}$ recurso quando provido por uma autoridade hierarquicamente superior trata-se de uma modalidade de accountability judicial decisional, já que esse processo permite que sejam analisadas as informações sobre o caso e a justificação sobre a decisão, alterando-se a decisão anterior.

18 Há um caso emblemático que é lembrado pela literatura sobre independência e accountability judiciais, o caso White (CARRINGTON, 1998,p. 115; ZEMANS, 1999, p. 627; BRODY, 2008, p. 10). Nesse caso, a juíza Penny White, da Suprema Corte do Tennessee, formou a maioria que manteve uma condenação de homicídio durante a prática de estupro, porém reformou a condenação à pena de morte pela inexistência de circunstância agravante. Em 1996, a juíza White foi submetida à eleição de manutenção-retenção. No Tennessee, para que um juiz permaneça no seu cargo por novo mandato, a maioria dos eleitores deve votar pela manutenção. Nesse ano, a Tennessee Conservative Union realizou uma campanha contra a retenção da juíza em razão da sua participação no referido julgamento. Como conseqüêcia do julgamento e da campanha contra a manutenção da magistrada, somente $45 \%$ dos eleitores foi favorável à retenção. Essa questão é utilizada como exemplo de que a accountability eleitoral dos magistrados, se usada como mecanismo de accountability decisional, afronta a independência judicial (BRODY, 2008, p. 10). valor que se relaciona com o Estado Democrático de Direito, especificamente com o império do direito (rule of law), com o constitucionalismo e com a democracia (FEREJOHN, 1999, p. 366-367). A independência judicial decisional é importante para aplicar as leis vigentes de maneira igualitária e manter a supremacia da constituição contra normas que são inconstitucionais, mesmo tendo sido aprovadas pelo poder Legislativo e sancionadas pelo poder Executivo.

Há, entretanto, um paradoxo entre independência judicial e accountability eleitoral. Tanto a independência como a accountability judicial decisional realizada por meio de eleições podem ser justificadas por argumentos democráticos. Os magistrados estão obrigados a seguir a legislação vigente, não podendo estabelecer uma situação como agravante se a legislação penal não a configura como tal. Por sua vez, os eleitores por meio do mecanismo típico da democracia representativa podem optar por sancionar um juiz com a sua não manutenção no cargo pelo conteúdo de sua decisão judicial. Em outras palavras, a democracia legitima a aplicação da independência judicial decisional e a accountability judicial decisional. Nesse dilema, segundo Ferejohn (FEREJOHN, 1999, p. 365-370), deve-se conceder primazia prima face à independência judicial decisional nos casos de conflito com a accountability judicial decisional.

$\mathrm{O}$ juiz deve ser influenciado pelos outros poderes e pelo povo, porém a influência dá-se por meio da obrigação de o magistrado aplicar a lei instituída democraticamente, desde que constitucional. Ainda, a influência popular dá-se pela discussão da interpretação das leis e da constituição feita pela esfera pública, pela sociedade civil e pelos membros dos poderes Executivo e Legislativo, podendo pela força do melhor argumento o magistrado alterar sua interpretação. Em questões muito importantes para a sociedade civil e para os poderes Executivo e Legislativo, existe a possibilidade de emenda à constituição para sobrestar ou alterar determinada interpretação constitucional dos tribunais. Desse modo, o espaço para aplicação da accountability judicial decisional é mais estreito em virtude da independência judicial decisional. Por outro lado, há a accountability judicial comportamental, a accountability judicial institucional e a independência judicial institucional.

Accountability judicial comportamental, como descrito anteriormente, reside na responsividade dos juízes pela sua conduta perante as partes, os advogados, os funcionários judiciais e o povo. Diversas características são albergadas sob a accountability judicial comportamental como imparcialidade, integridade, urbanidade e eficiência na prestação judicial, não havendo afronta pelo seu exercício à 
independência judicial decisional (BRODY, 2008, p. 10). Por sua vez, a accountability judicial comportamental traz um problema clássico de accountability: a dificuldade de obtenção de informações e dados para mensurar o cumprimento pelos agentes dos deveres e dos resultados esperados.

A construção de um poder Judiciário dotado de independência decisional e de accountability comportamental envolve uma série de fatores. De um lado, como coloca Ferejohn (1999, p. 354-355), é central a forma de nomeação de magistrados para que cumpram suas funções de maneira adequada nos termos da accountability judicial comportamental e julguem em conformidade com a interpretação dos fatos, da lei e da constituição. Outra questão diz respeito à maneira como as relações de accountability judicial comportamental são desenhadas, sendo importante se os magistrados terão sua accountability avaliada de maneira direta ou indireta pelo povo.

Outra dimensão relevante da independência e da accountability judiciais diz respeito ao aspecto institucional. No exercício da função jurisdicional, os magistrados atuam como agentes estatais de accountability horizontal em relação aos poderes Executivo e Legislativo. O poder Judiciário também se encontra em um modelo de desenho institucional de checks and balances, o qual constrói interações e limitações recíprocas entre os três poderes. Nesse contexto, a independência judicial institucional diz respeito à autonomia de que goza o poder Judiciário por ser um poder estatal independente dotado da função primeira de julgar os conflitos jurídicos ${ }^{19}$. Nesse sentido, a accountability judicial institucional diz respeito principalmente às relações de accountability horizontal que restringem e moldam a independência judicial institucional.

Como coloca Ferejohn (1999, p. 353-354), a independência que o poder Judiciário goza como instituição autônoma e independente permite aos juízes exercerem a independência judicial decisional. Em outras palavras, a independência judicial institucional é uma condição necessária, porém não suficiente, para que os magistrados desenvolvam a livre interpretação dos fatos, da lei e da constituição. Existe completa independência de uma pessoa ou de um órgão se suas ações não dependem de outra pessoa ou instituição. Nesse sentido, o poder Judiciário não é totalmente independente, pois a definição da jurisdição, as normas procedimentais e a execução das ordens judiciais

19 Sobre a independência judicial institucional e accountability judicial institucional, ver Geyh (2003, p. 163). dependem dos poderes Legislativo e Executivo ${ }^{20}$. A questão é: as interferências institucionais dos outros poderes no poder Judiciário não podem, prima facie, afrontar a independência judicial decisional dos magistrados em um caso específico.

A análise da conformação da independência judicial institucional da magistratura federal norte-americana auxilia, apesar das peculiaridades históricas e institucionais, na compreensão de desenho institucional da independência das magistraturas nos Estados Democráticos de Direito. Segundo Geyh (2003, p. 221222), a independência judicial institucional foi construída a partir do embate entre a Suprema Corte NorteAmericana e os poderes Executivo e Legislativo federais em seis momentos nos mais de 200 anos de federação norte-americana ${ }^{21}$. Por meio da história institucional, o autor conclui que o poder Legislativo historicamente deixou de utilizar suas competências em relação ao poder Judiciário para interferir na independência judicial decisional e, gradativamente, aumentou as autonomias financeira e administrativa do poder Judiciário. Por sua vez, a única forma que o poder Legislativo atualmente utiliza para influenciar a independência judicial decisional encontra-se na aprovação, no Senado federal, dos indicados à magistratura federal.

A interpretação que o presidente e, principalmente, o poder Legislativo fazem das independências judiciais decisional e institucional estabelecem um padrão interpretativo da constituição. Apesar de esses agentes estatais poderem ter várias interpretações sobre a

20 Por exemplo, o Congresso norte-americano possui competência para interferir institucionalmente no poder Judiciário nas seguintes questões: $(i)$ criar outros tribunais além da Suprema Corte e regular a competência judicial federal; (ii) estabelecer o número de juízes e sua distribuição nos tribunais; (iii) atribuir receita ao poder Judiciário pelo orçamento; (iv) criar regras processuais; $(v)$ isolar as decisões dos tribunais estaduais de revisão federal e (vi) superar certas decisões judiciais (FEREJOHN, 1999, p. 355). Ocorre um problema institucional quando o poder Legislativo procura alterar o desenho da competência judicial, direcionando a análise de caso jurídico específico. Por outro lado, o legislador pode alterar a competência do poder Judiciário federal com o intuito de melhor racionalizar o sistema judicial (idem, p. 355). Geyh (2003, p. 164) apresenta também dois exemplos interessantes de controle institucional do legislativo sobre o poder Judiciário. Para o autor, é inadequado institucionalmente o legislativo cortar o orçamento do Judiciário como medida de retaliação por uma decisão judicial, mas é um elemento importante do Estado Democrático de Direito que os políticos façam todas as críticas que julguem pertinentes às decisões judiciais.

21 Esses seis momentos são: (i) início do século XIX; (ii) disputa da corte Marshall com a administração Jackson; (iii) Guerra Civil e caso Dred Scott; (iv) New Deal e crítica à Suprema Corte por Roosevelt; ( $v$ ) corte Warren e (vi) o momento atual (GEYH, 2003, p. 166). 
independência judicial a partir do texto constitucional, eles firmam costumes constitucionais que perduram por anos e, alguns, por séculos. Desse modo, as mudanças interpretativas que os membros do Legislativo e do Executivo procuram implantar representam alterações em costumes constitucionais. Assim, esses agentes institucionais possuem forte ônus argumentativo de provar que a nova interpretação encontra-se de acordo com a constituição, sendo a concepção anterior equivocada (GEYH, 2003, p. $166)^{22}$. Além disso, a criação da conferência judicial e do escritório administrativo dos tribunais dos Estados Unidos mudou o foco da independência judicial institucional e ampliaram a accountability judicial interna. Essas ações concederem grande autonomia institucional ao poder Judiciário federal norteamericano (GEYH, 2003, p. 209) ${ }^{23}$.

Entretanto, a grande independência judicial institucional e a forte participação política do poder Judiciário, principalmente pelo controle de constitucionalidade, podem debilitar os mecanismos de accountabilities judiciais internos. Uma resposta institucional a esse problema encontra-se na criação de conselhos de justiça, com o objetivo de ampliar as accountabilities comportamental e institucional, porém não por meio de controle externo, e sim interno. Esse é o caso do Conselho Nacional de Justiça (CNJ).

\section{ACCOUNTABILITY E INDEPENDÊNCIA JU- DICIAIS: CONSTITUIÇÃO FEDERAL DE 1988, REFORMA DO JUDICIÁRIO E CONSELHO NACIONAL DE JUSTIÇA (CNJ)}

As relações de accountabilities judiciais, analisadas

\footnotetext{
22 Sobre os costumes constitucionais acerca da independência judicial, deve-se pontuar ( $i$ ) a impossibilidade de impeachment dos magistrados por problemas de accountability judicial comportamental e por decisões que contrariam a interpretação constitucional feita pelos agentes eleitos do legislativo; (ii) a tendência de manutenção no número de magistrados nos tribunais; (iii) a vedação de proibição de apreciação judicial de casos específicos por legislação; (iv) a preocupação com a eficiência judicial e concessão de autonomia administrativa e financeira ao poder Judiciário e $(v)$ o estabelecimento da sabatina do Senado como mecanismo legitimo para influenciar o processo de independência judicial decisional (GEYH, 2003, p. 169-170).

23 A independência institucional e o exercício da accountability judicial comportamental pelo próprio poder Judiciário americano foram expandidas, em 1966, pela criação do Federal Judicial Center (FJC), que possuía três objetivos principais: $(i)$ realizar e conduzir pesquisas sobre o exercício da jurisdição nos tribunais federais; (ii) oferecer educação legal e (iii) estudar como a computação e o processamento de dados pode melhorar a prestação judicial. Também foi estabelecido o Judicial Councils Reform and Judicial Conduct and Disability Act, em 1980, constituindo uma estrutura administrativa judicial que possibilitava exercer o poder disciplinar sobre os juízes (GEYH, 2003, p. 210-211).
}

anteriormente, são conformadas pelos arranjos institucionais do Estado Democrático de Direito, que estabelece a gradação entre independência e controle do poder Judiciário, como poder constitucionalizado, e dos magistrados e tribunais, como atores individuais e coletivos. No Brasil, a Constituição Federal de 1988 ampliou significativamente a independência judicial. Por outro lado, a Reforma do Judiciário, promovida pela Emenda Constitucional 45/2004, e, em especial, pela criação do Conselho Nacional de Justiça (CNJ), alterou o equilíbrio entre accountability e independência judiciais.

A existência de uma organização (burocracias ou poder Judiciário) livre de accountability eleitoral amplifica a independência desses agentes. Sobretudo quando essas organizações possuem elevado grau de garantias funcionais. Nesses casos, há uma grave limitação para a ocorrência de formas eficientes de accountability. Além disso, a forma de investidura em cargo público por concursos públicos de provas e títulos produz organizações qualificadas, mas não necessariamente accountable.

A mudança das instituições brasileiras, pelas prescrições previstas no texto constitucional de 1988 e na accountability no Brasil ${ }^{24}$, representou uma importante conquista na construção do Estado Democrático de Direito. Entretanto, a legitimidade democrática dos agentes não eleitos continuou limitada. Como não há accountability eleitoral sobre esses agentes, a literatura sugere o funcionamento de mecanismos de accountability horizontal e outras formas de accountability vertical. Essa questão é fundamental na análise do poder Judiciário brasileiro.

Isso não significa que após 1988 nenhuma forma de controle foi imposta ao poder Judiciário. A manifestação dos cidadãos, das associações e da imprensa pode expor publicamente um agente público (accountability social). Em decorrência disso, cidadãos, associações e agentes públicos podem formular requerimentos administrativos ou ações judiciais, pleiteando que as autoridades competentes sancionem os agentes estatais (accountability horizontal).

No poder Judiciário, especificamente, a nomeação presidencial de magistrados de tribunais superiores após aprovação pelo Senado constitui-se em um mecanismo de accountability que o poder Executivo e o poder Legislativo federais podem exercer sem violar a independência judicial decisional. Dessa forma, o momento de indicação e de sabatina, além de observar

\footnotetext{
24 Para uma visão panorâmica sobre a accountability na Constituição Federal de 1988, ver. Romêo (2009, p. 179-188) e Mota (2006, p. 103-133).
} 
as competências técnicas, o passado e a honestidade, pode explicitar a ideologia e conveniência de nomeação dos candidatos.

Esse mecanismo de nomeação é uma forma de interferência legítima, dado que a Constituição Federal de 1988 ampliou o papel institucional do poder Judiciário no controle das demais autoridades públicas (eleitas ou não). Uma forma desse controle dá-se pelo princípio da inafastabilidade da jurisdição. Desse modo, os cidadãos podem requerer ao poder Judiciário a aplicação de sanções contra atos dos agentes estatais. Trata-se de um mecanismo de accountability horizontal. Também, o poder Judiciário exerce accountability horizontal quando julga os conflitos entre agentes estatais entre si.

\section{QUADRO 2 - GARANTIAS INSTITUCIONAIS E FUNCIONAIS DO JUDICIÁRIO (CF 1988)}

\begin{tabular}{|ll|}
\hline Autogoverno & $\begin{array}{l}\text { Tribunais elegem sua cúpula diretiva e elaboram os seus regimentos internos (art. 96, I, } \\
\text { Constituição Federal (doravante “CF”)); tribunais, com participação da OAB, formulam } \\
\text { concursos públicos para o ingresso na carreira de juiz substituto (magistrados de início } \\
\text { de carreira). }\end{array}$ \\
\hline $\begin{array}{l}\text { Judiciário propõe privativamente, ao Congresso, projetos de lei sobre: Estatuto da } \\
\text { Magistratura (art. 93, caput, CF); criação de novas varas judiciárias (art. 95, I, 'd', CF); } \\
\text { iniciativa de leis }\end{array}$ & $\begin{array}{l}\text { alteração do número de magistrados dos tribunais inferiores (art. 95, II, 'a', CF); criação, } \\
\text { extinção e remuneração de cargos de juízes e dos serviços auxiliares (art. 95, II, 'b', CF); } \\
\text { criação e extinção de tribunais (art. 95, II, 'c', CF) e a mudança da organização e divisão } \\
\text { judiciárias (art. 95, II, 'd', CF). }\end{array}$ \\
\hline $\begin{array}{l}\text { Administração } \\
\text { financeira }\end{array}$ & $\begin{array}{l}\text { Compete ao poder Judiciário apresentar sua proposta de orçamento (art. 99, CF), } \\
\text { recebendo em duodécimos a dotação orçamentária (art. 168, CF). }\end{array}$ \\
\hline $\begin{array}{l}\text { Garantias } \\
\text { funcionais aos } \\
\text { magistrados }\end{array}$ & $\begin{array}{l}\text { Vitaliciedade, inamovibilidade e irredutibilidade de vencimentos (art. 95, I, II e III, CF), } \\
\text { sendo previstas vedaçães: ao exercício de outro cargo público com exceção de } \\
\text { magistério superior; ao recebimento de custas ou à participação em atividade político- } \\
\text { partidária (art. 95, parágrafo único, CF). }\end{array}$ \\
\hline
\end{tabular}

FONTE: Os autores, a partir da Constituição Federal de 1988.

Além de ser dotado constitucionalmente de extensos poderes, conforme afirma Clève (2011a, p. 660), aparentemente, não existe um poder Judiciário com maior independência do que o brasileiro. No Brasil, o poder Judiciário possui extenso rol de garantias institucionais e de garantias funcionais, gerando, por decorrência, suporte constitucional às independências judiciais decisional e institucional (ver Quadro 2). Garantias incomuns, inclusive, ao poderoso poder Judiciário norte-americano.

Talvez devido à elevada independência judicial, a Constituição de 1988 , no que se refere às decisões, ampliou as competências recursais, permitindo aos jurisdicionados apresentarem grande número de recursos contra decisões. Isso reforça a modalidade de accountability judicial decisional interna. Por meio da possibilidade de os litigantes apresentarem recursos, há garantias de que os fatos avaliados equivocadamente sejam revistos e de que uma decisão relevante possa ser avaliada por outros magistrados.

A existência de recursos judiciais ganha ainda mais relevo no Brasil, que possui controle difuso de constitucionalidade. Desse modo, os magistrados são responsáveis por garantir direitos previstos constitucionalmente, podendo no caso concreto trazido à jurisdição declarar a inconstitucionalidade de leis e atos normativos que na sua livre interpretação violam a
Constituição. Por outro lado, como existem diversas interpretações possíveis para um mesmo texto legal e há a presunção de constitucionalidade das leis, nada mais adequado que permitir uma revisão dessa interpretação por meio de recurso judicial. Também se observam os princípios da publicidade e da motivação das decisões ${ }^{25}$. Esses dispositivos garantem a efetivação dos elementos da accountability decisional ${ }^{26}$. Além disso, reforçando o papel institucional do poder Judiciário na Constituição de 1988, ampliou-se a

25 Nos termos do art. 93, IX, CF, os julgamentos dos órgãos do poder Judiciário são públicos, podendo existir limitação à publicidade por lei em razão do interesse público. Também, o art. 93, IX e X, CF, impõe a motivação das decisões judiciais e das decisões administrativas de juízes e de tribunais.

26 Apenas com esses elementos, os litigantes podem apresentar os recursos cabíveis. Também, por meio da análise de casos e de decisões, os estudiosos do direito podem refletir sobre os julgados, apontando equívocos e críticas. De certa forma a doutrina crítica pode funcionar como sujeito de accountability social. Na análise de importantes decisões jurídicas, a doutrina pode expor publicamente os equívocos que a partir de determinadas construções teóricas os magistrados incorreram. Essa função da doutrina pode aplicar a sanção branda da accountability social de exposição pública, podendo essa decisão ser revista no futuro em caso semelhante e por recurso judicial. Esse papel crítico dos juristas torna-se ainda mais relevante em virtude da ampliação das ações de controle concentrado de 
accountability institucional dos poderes Executivo e Legislativo por meio de controle concentrado de constitucionalidade no STF através $(i)$ da concessão de maior independência institucional ao ministério público e (ii) da ampliação do rol de legitimados ativos para a propositura de controle concentrado ${ }^{27}$.

Pela apresentação do desenho constitucional (garantias e prerrogativas) do poder Judiciário brasileiro, a concepção de que esse é um poder extremamente dependente do poder Executivo, defendida por Campos (1990) e por O'Donnell (1998), encontra-se, no mínimo, equivocada. A independência institucional do poder Judiciário brasileira é extensa. $\mathrm{Em}$ virtude das garantias institucionais e funcionais do poder Judiciário e do amplo grau de controle de constitucionalidade judicial (difuso e concentrado), o desenho institucional permite forte participação do poder Judiciário como ator político ${ }^{28}$.

A accountability judicial decisional no Brasil acontece por meio (i) do sistema recursal, (ii) do processo de indicação do magistrado de tribunais superiores pelo Presidente da República e aprovação

constitucionalidade e dos legitimados ativos. Até o advento da Constituição de 1988, somente o procurador geral da república era legitimado para propor representação por inconstitucionalidade de lei ou ato normativo federal.

27 Os legitimados para a propositura da ação direta de inconstitucionalidade (ADI), ação declaratória de constitucionalidade (ADC) e arguição de descumprimento de preceito fundamental (ADPF) são, de acordo com o art. 103, CF: (i) Presidente da República; (ii) mesa do Senado federal; (iii) mesa da Câmara dos Deputados; (iv) mesa da Assembléia Legislativa ou da Câmara Legislativa do Distrito Federal; (v) Governador de Estado ou do Distrito Federal; (vi) Procurador Geral da República; (vii) conselho federal da Ordem dos Advogados do Brasil; (viii) partido político com representação no Congresso Nacional e (ix) confederação sindical ou entidade de classe de âmbito nacional.

28 Por exemplo, a independência judicial decisional aliada à previsão de direitos sociais e da estrutura do Estado Social de Direito na Constituição de 1988 permitiu que grupos da sociedade civil requeressem aos juízes competentes a invalidação dos processos de privatização e de reformas constitucionais como da previdência. Sadek (1999, p. 298) define esse fenômeno como guerrilha de liminares onde, por meio de ações civis públicas, associações obtinham liminares (na justiça federal de primeira instância) suspendendo e invalidando ações dos poderes Legislativo e Executivo. Esse processo, definido pela literatura como judicialização, é classificado por Ferejohn (2002, p. 41) em: (i) imposição de limites ao Legislativo e ao Executivo nas decisões legais; (ii) formulação de políticas públicas a partir da aplicação da livre interpretação da constituição e (iii) regulação dos comportamentos políticos de grupos de interesses, partidos políticos e agentes estatais nos processos e nos procedimentos democráticos e eleitorais. Todas essas modalidades estão presentes na jurisdicionalidade brasileira posterior a 1988 . do Senado federal e (iii) da discussão crítica da doutrina e da sociedade civil, a qual se encontra amparada pela liberdade de expressão e pensamento. Por outro lado, a independência judicial institucional é grande em virtude das autonomias institucionais (autogoverno, autoadministração, competência de iniciativa de leis relevantes para a magistratura e a autonomia orçamentária), das garantias funcionais (vitaliciedade, inamovibilidade e irredutibilidade dos vencimentos) e do processo de seleção de juízes substitutos pelo próprio poder Judiciário.

Quanto à accountability judicial comportamental, que reside na responsividade dos juízes por sua conduta perante as partes, os advogados, os funcionários judiciais e os cidadãos (BRODY, 2008, p. 10), a Constituição de 1988 não instituiu mecanismos eficazes que permitissem contrabalançar o elevado grau de autonomia institucional do poder Judiciário ${ }^{29}$. Nessa forma de accountability diversas características são albergadas como imparcialidade, integridade, urbanidade e eficiência na prestação judicial. Como prêmio ou sanção pelo comportamento do magistrado encontra-se a promoção, sendo que esta acontece alternadamente por antigüidade e por merecimento.

Essa forma de valorizar o merecimento é insuficiente para concretizar a accountability judicial comportamental. A razão é simples: aqueles que não buscam desenvolver um prestação jurisdicional eficiente e um constante aperfeiçoamento serão promovidos por antigüidade $^{30}$. Antes da Constituição de 1988, o poder disciplinar era exercido pelo tribunal que se encontrava vinculado o magistrado e pelo Conselho Nacional da Magistratura. Para o exercício do poder disciplinar, existem as corregedorias de justiça dos tribunais. Após a Constituição de 1988, as corregedorias e os tribunais exerciam controle sobre os magistrados de primeiro grau, porém não realizavam uma fiscalização substancial sobre os juízes de segundo grau.

Desse modo, pela análise do desenho institucional do poder Judiciário brasileiro, encontra-se correto O'Donnell (2009) quando afirmou que o poder Judiciário brasileiro é um agente de accountability

29 A accountability judicial comportamental é disciplinada pela Lei Orgânica da Magistratura, a qual deve necessariamente obedecer a uma série de comandos postos na Constituição de 1988 e, em especial, pelo art. 93, CF. A lei complementar n. 35/ 1979 foi parcialmente recepcionada pela constituição, sendo a Lei Orgânica da Magistratura atualmente vigente.

30 De acordo com o art. 93, II, 'd', CF, somente não será promovido por antigüidade o magistrado que for rejeitado por dois terços dos magistrados do seu tribunal. Essa forma de desenho institucional das promoções não produz incentivos adequados para a melhoria da prestação jurisprudencial e da accountability judicial comportamental. 
horizontal relevante após a Constituição de 1988, mas com severos déficits de accountabilities interno e externo. Apesar de existirem deveres judiciais previstos no Estatuto da Magistratura, não se observava um desenho institucional do poder Judiciário com adequados incentivos para a realização da accountability judicial comportamental. Além disso, após 1988, aconteceu uma explosão de demandas apresentadas à jurisdição. Essas questões são responsáveis pela ampliação da relevância e do impacto social do poder Judiciário, além de serem indicadas como importantes fenômenos da "crise" do poder Judiciário ${ }^{31}$. A ampliação da provocação do poder Judiciário também aumentou a busca por celeridade e pela eficiência na prestação jurisdicional. Diversas foram as reformas na legislação com o intuito de ampliar a celeridade processual ${ }^{32}$.

A relevância que o poder Judiciário adquiriu no Brasil, principalmente em razão da maior participação do poder Judiciário na sociedade com a judicialização da política e do aumento das demandas, colocou em debate, desde a década de 1990, diversas propostas de reforma do poder Judiciário. Essas reformas possuíam dois focos principais: (i) tornar a jurisdição mais célere e (ii) estabelecer uma melhor accountability do poder Judiciário.

A busca por celeridade judicial em parte podia ser efetivada com alteração da legislação infraconstitucional, como no caso das mudanças do processo civil. Por outro lado, uma reforma mais profunda na questão da celeridade e no estabelecimento de maiores redes de accountability judicial comportamental e institucional exigia alterações no desenho constitucional brasileiro ${ }^{33}$. Na reforma do poder Judiciário havia a discussão sobre como a revisão do processo de accountability judicial institucional pode incrementar a accountability judicial comportamental. Esse foi o caso de duas iniciativas de

\footnotetext{
${ }^{31}$ Um dado pode ilustrar bem essa ampliação na demanda por justiça. Em 1990, na justiça comum de primeiro grau foram propostos 3617064 processos e julgados 2411847 . No ano de 2002, por sua vez, foram apresentados 9764616 e julgados 7506697 (SADEK, 2004, p. 13). Desse modo, dependendo do ramo do poder Judiciário, em 2002, seriam necessários de cinco a oito anos sem entrada de novos processos para que todos os antigos fossem julgados (SADEK, 2004, p. 20).

32 São exemplos: a Lei n. 8 952/1994, que estabeleceu a antecipação de tutela, e a Lei n. 10 444/2002, que regulamentou a tutela específica.

33 Em 1992, o Deputado Federal Hélio Bicudo de São Paulo apresentou a PEC 96/92. O principal argumento da proposta encontra-se na idéia de que o governo brasileiro não redesenhou institucionalmente o poder Judiciário de maneira adequada, não concedendo incentivos e estruturas para que os magistrados cumprissem suas funções plenamente. Essa situação gerou a crise avassaladora do poder Judiciário (BRASIL, 1992a, p. 7850).
}

reformas do poder Judiciário: a PEC $96 / 92^{34}$ e a PEC $112 / 95^{35}$. O desenho institucional previsto na PEC 112/ 95 demonstra que os conselhos de magistratura (federal e estadual) propostos buscavam efetivar a accountability em contexto de grande independência judicial.

Desde a PEC 96/92, transcorreram 12 anos para que o Congresso aprovasse uma ampla reforma sobre o poder Judiciário brasileiro, a qual estabeleceu, entre diversos dispositivos, um Conselho Nacional de Justiça (CNJ) com competência sobre as magistraturas federal e estaduais. A criação de um conselho de justiça com membros externos atraia repulsa da maior parte da magistratura. Apesar de a emenda constitucional 45/04 ter criado o $\mathrm{CNJ}$ com maioria de conselheiros juízes e sob a presidência de um ministro do STF, estabeleceuse um conselho de magistratura com membros externos.

A reforma do poder Judiciário foi estabelecida como prioritária logo no início do primeiro mandato do governo Lula. Em 2003, o Ministério da Justiça criou a Secretaria de Reforma do Poder Judiciário, sendo promulgada no final de 2004 a emenda 45/04. Em verdade, o que fez o governo Lula foi estabelecer consensos políticos com os legisladores para aprovar a PEC 96/92, conforme a redação final formulada pela Deputada Federal Zulaiê Cobra (BRASIL, 2000). A maior parte dessa redação final da PEC 96/92 foi aprovada em 2004.

34 Esse trecho capta o problema principal que deveria ser enfrentado pela reforma do poder Judiciário pela proposta da PEC 96/92: "Na verdade, o problema é mais profundo, porque o Poder Judiciário é, dentre os três Poderes da República, o único infenso à fiscalização. Enquanto o Executivo é fiscalizado pelo Legislativo, este pelo povo e ambos pelo Poder Judiciário. Os juízes não se submetem a qualquer modalidade de censura externa" (BRASIL, 1992a, p. 7852). A PEC n. 96/92 propôs mudanças no processo de seleção, promoção e vitaliciedade para os juízes substitutos, além de alterar o processo de nomeação de magistrados no STF e no STJ. A promoção por merecimento, por sua vez, não seria analisada apenas pelos membros dos tribunais.

35 O Deputado Federal José Genoíno formulou a PEC 112/95 (BRASIL, 1995) que propunha regulamentar e criar o sistema de controle do poder judicial com três órgãos (Conselho Federal de Justiça, Conselhos Estaduais de Justiça e Conselho Distrital de Justiça), não podendo interferir no mérito das decisões judiciais e nas atividades jurisdicionais. Conforme informa Clève (2011a, p. 666-667), desde a constituinte ocorre a discussão sobre a criação de um órgão de controle externo do poder Judiciário, sendo composto pelos representantes dos outros poderes e do poder Judiciário. Sobre o controle externo do poder Judiciário, essa temática já foi enfrentada pela Comissão Afonso Arinos em 1986. Com o apoio de juristas como Nelson Jobim, Nilo Batista e Márcio Thomaz Bastos, na Comissão de Sistematização da Constituinte, o Conselho Nacional de Justiça foi previsto no art. 151 do Projeto A de Constituição (SAMPAIO, 2007, p. 241). 
QUADRO 3 - EC 45/2004: REFORMA DO JUDICIÁRIO, CNJ E ACCOUNTABILITY JUDICIAL

\begin{tabular}{|ll|}
\hline Artigo 5, LXXVIII, CF & Razoável duração do processo e os meios para celeridade processual \\
\hline Artigo 92, I-A, CF & Criação do CNJ (Conselho Nacional de Justiça) \\
\hline Artigo 93, I, CF & Ingresso na Magistratura com no mínimo três anos de atividade jurídica \\
\hline Artigo 93, II, 'c', CF & $\begin{array}{l}\text { Aferição do merecimento para fins de promoção, mensurado por critérios objetivos } \\
\text { de produtividade e presteza no exercício da jurisdição }\end{array}$ \\
\hline Artigo 93, II, 'e', CF & $\begin{array}{l}\text { Proíbe a promoção de magistrado que retivesse em seu gabinete injustificadamente } \\
\text { processo além do prazo legal }\end{array}$ \\
\hline Artigo 93, IV, CF & Obrigatoriedade de curso de preparação para a vitaliciedade. \\
\hline Artigo 93, VIII, CF & Remoção, disponibilidade e aposentadoria julgadas pelo tribunal e CNJ \\
\hline Artigo 93, X, CF & Sessões administrativas dos tribunais públicas e decisões motivadas \\
\hline Artigo 93, XIV e XV, CF & $\begin{array}{l}\text { Delegação de poder para funcionários praticar atos administrativos e distribuição } \\
\text { imediata de processo. }\end{array}$ \\
\hline Artigo 103-A, CF & Súmula vinculante pelo STF \\
\hline
\end{tabular}

FONTE: Os autores, a partir da Constituição Federal de 1988.

A eficiência na prestação jurisdicional, centro da reforma do poder Judiciário (EC 45/2004), é um importante elemento que compõe a accountability judicial comportamental (ver Quadro 3). Além disso, a reforma abordou a crítica à ausência de experiência de jovens magistrados, que acabava prejudicando a prestação jurisdicional adequada e segura (SADEK, 2004, p. 22). Por fim, criou mecanismos de promoção em que o merecimento deveria ser analisado por meio da quantidade de despachos, de sentenças e de acórdãos prolatados por um magistrado e pelo fiel cumprimento dos prazos processuais. Sobre a aquisição da garantia funcional da vitaliciedade, não se concretizou a proposta que ampliava a accountability judicial institucional ao introduzir avaliação do conselho de justiça, da OAB e do ministério público. Por outro lado, determinou-se a participação obrigatória em curso oficial de preparação para a obtenção de vitaliciedade.

A remoção, a disponibilidade e a aposentadoria, por interesse público, passaram a ser julgadas pelo tribunal e pelo CNJ. A redação final da PEC 96/92 previa a possibilidade de o CNJ aplicar como sanção disciplinar a perda de cargo aos magistrados por três quintos dos membros (BRASIL, 2000, p. 30905). Esse dispositivo não foi aprovado. Desse modo, apenas por meio de sentença judicial pode o magistrado perder o cargo, sendo a maior sanção disciplinar administrativa a aposentadoria com proventos proporcionais ao tempo de serviço. A impossibilidade de aplicar sanção administrativa de perda de cargo diminui a accountability judicial comportamental.

Há outros elementos de accountability judicial comportamental introduzidos na reforma do poder Judiciário e, em especial, com foco na eficiência. $\mathrm{O}$ art. 93, X, CF, prescreveu que as sessões administrativas dos tribunais serão públicas, além de as decisões motivadas. O elemento publicidade (informações) é requisito sine qua non para qualquer modalidade de accountability, sendo comum outrora a realização de sessões administrativas restritas ao público nos tribunais.

Nesse mesmo sentido, a emenda determinou que a organização judiciária e a lotação de magistrados em comarcas e seções serão proporcionais à demanda por prestação jurisdicional e à população. Trata-se de medida que busca estabelecer uma estrutura judiciária adequada às ações propostas, sendo regra importante para efetivar o direito fundamental à prestação judicial em tempo razoável. Além disso, autorizou a delegação de poder para funcionários do poder Judiciário praticar atos administrativos e de mero expediente, além de impor a distribuição imediata de processo. Por um lado, a delegação permite que os juízes foquem seu tempo na sua atividade fim de prestação jurisdicional. A distribuição imediata impõe a abertura dos prazos processuais legais para manifestação do juiz com sanções pelo não cumprimento (impossibilidade de promoção por merecimento) e obriga o magistrado a analisar os pedidos de liminares.

Por fim, outro instrumento para concretizar o direito fundamental à razoável prestação jurisdicional encontra-se no estabelecimento de súmula vinculante pelo STF. Depois de reiteradas decisões do STF sobre uma matéria, dois terços dos ministros podem editar súmula vinculante, a qual deve ser seguida por todo o poder Judiciário e pelas administrações públicas direta e indireta. $\mathrm{O}$ objetivo é que o STF fixe entendimento sobre a matéria, encerrando discussões que aumentavam a proposição de recursos.

O CNJ foi previsto no art. 103-B, CF, sendo composto por 15 membros. O mandato dos conselheiros é de dois anos com uma possível 
recondução ${ }^{36}$. O Ministro do STF preside o conselho, cabendo a nomeação de todos os membros do CNJ pelo Presidente da República após aprovação dos candidatos pelo Senado federal (art. 103-B, $\S \S 1^{\circ}, 2^{\circ}$ e $\left.3^{\circ}, \mathrm{CF}\right)$. No que se refere à composição do $\mathrm{CNJ}$, há $60 \%$ (nove) dos membros juízes e $40 \%$ (seis) dos conselheiros não magistrados. Desse modo, pela análise da composição, observa-se que se mantém forte independência judicial institucional, já que o Presidente do Conselho, o Corregedor de Justiça e a maioria dos membros do conselho são magistrados. De outro lado, há também elementos de accountability judicial institucional externa na composição do conselho, pois quatro membros são profissionais essenciais à função da jurisdição (advogados e membros do ministério público) e dois membros são cidadãos de "notável saber jurídico"37.

Não existe dúvida de que a composição do $\mathrm{CNJ}$ com uma maioria de magistrados auxiliou na aprovação EC 45/04 e diminuiu a crítica dos magistrados sobre o estabelecimento do conselho ${ }^{38}$. Partindo do pressuposto de que existe grande independência judicial institucional e déficits de accountability judicial institucional, seria mais adequada à concretização da composição prevista na PEC 112/95.
O CNJ constitui-se em órgão responsável por exercer accountability sobre outros agentes estatais como tribunais, magistrados, serviços auxiliares, prestadores de serviço notarial e de registro que atuam por delegação. Desse modo, a principal modalidade de accountability praticada pelo CNJ é a accountability horizontal, mas, como será visto abaixo, esse órgão também desempenha elementos de accountability vertical não eleitoral. Por meio de instrumentos de accountabilities horizontal ou vertical não eleitoral, o CNJ implementa accountabilities judicial comportamental e institucional. Não existe competência de accountability judicial decisional, pois o conselho não exerce poder jurisdicional originário ou recursal. $\mathrm{O}$ art. 103-B, $\S 4^{\circ}, \mathrm{I}, \mathrm{CF}$, afirma que compete ao CNJ zelar pela autonomia e pelo cumprimento do Estatuto da Magistratura.

O desenho institucional após a Constituição Federal de 1988 não criou incentivos para a fiscalização e o controle dos membros do tribunal. Desse modo, a criação do CNJ e a competência para o cumprimento do Estatuto da Magistratura, em especial do Título III da disciplina judiciária, mostram-se fundamentais. Essa é uma forma de accountability horizontal exercida pelo CNJ sobre magistrados e órgãos judiciais (ver Quadro 4).

\section{QUADRO 4 - COMPETÊNCIAS CONSTITUCIONAIS E INFRACONSTITUCIONAIS DO CNJ}

\begin{tabular}{|c|c|}
\hline $\begin{array}{l}\text { Inciso I, do parágrafo } 4^{\circ} \\
\text { do art. } 103-B, C F\end{array}$ & $\begin{array}{l}\text { Expede atos regulamentares no âmbito de sua competência. (accountability } \\
\text { horizontal sobre magistrados, servidores auxiliares, órgãos judiciais e serviços } \\
\text { notariais). }\end{array}$ \\
\hline $\begin{array}{l}\text { Inciso II, do art. 103-B, } \\
\text { CF }\end{array}$ & $\begin{array}{l}\text { Zela pela observância do art. } 37 \text { da CF (fiscalização do cumprimento dos princípios } \\
\text { da legalidade, da impessoalidade, da moralidade, publicidade e eficiência). }\end{array}$ \\
\hline Art. 103-B, II, CF & Apreciar a legalidade de atos administrativos praticados pelo poder Judiciário \\
\hline $\begin{array}{l}\text { Inciso VII do art. 103-B, } \\
\text { CF }\end{array}$ & $\begin{array}{l}\text { Formula relatório anual sobre o contexto e a situação do poder Judiciário (mensagem } \\
\text { remetida pelo STF ao Congresso). }\end{array}$ \\
\hline Art. 103-B, $\S 7^{\circ}$, CF & $\begin{array}{l}\text { Cria Ouvidorias de Justiça (estados e União) para o recebimento de denúncias contra } \\
\text { magistrados e servidores auxiliares. }\end{array}$ \\
\hline Lei n. 12.106 de 2009 & $\begin{array}{l}\text { Departamento de Monitoramento e Fiscalização do Sistema Carcerário e do Sistema } \\
\text { de Execução de Medidas Socioeducativas (DMF) (mutirões carcerários). }\end{array}$ \\
\hline $\begin{array}{l}\text { Resolução n. 102/09 do } \\
\text { CNJ }\end{array}$ & $\begin{array}{l}\text { Impõe a publicação pelos tribunais de informações administrativas e financeiras dos } \\
\text { tribunais, com exceção do STF (informações sobre: gestões orçamentárias, } \\
\text { remuneração e quantitativo dos funcionários, relação de magistrados). }\end{array}$ \\
\hline $\begin{array}{l}\text { Resolução n. 103/10 do } \\
\text { CNJ }\end{array}$ & Cria Ouvidoria do CNJ e a criação de ouvidorias nos tribunais. \\
\hline $\begin{array}{l}\text { Resolução n. } 76 / 09 \text { do } \\
\text { CNJ }\end{array}$ & $\begin{array}{l}\text { Informação sobre dados estatísticos sob a competência do CNJ (Sistema de } \\
\text { Estatísticas do Poder Judiciário - Siespj). }\end{array}$ \\
\hline $\begin{array}{l}\text { Resolução n. 83/09 do } \\
\text { CNJ }\end{array}$ & Disciplina a aquisição, a locação e o uso de veículos judiciais pelo poder Judiciário. \\
\hline Resolução n. 70/09 & $\begin{array}{l}\text { Determina os valores institucionais e comportamentais do poder Judiciário } \\
\text { (credibilidade, acessibilidade, celeridade, ética, imparcialidade, modernidade, } \\
\text { probidade, responsabilidades sociais e ambiental e transparência) (15 objetivos } \\
\text { separados em oito temas). }\end{array}$ \\
\hline RICNJ & $\begin{array}{l}\text { Poder disciplinar do CNJ, o corregedor nacional de justiça exerce correições e } \\
\text { inspeções sobre os órgãos do poder Judiciário. }\end{array}$ \\
\hline
\end{tabular}

FONTE: Os autores, a partir da Constituição Federal de 1988.

36 No que se refere à composição do CNJ, os conselheiros são (i) Ministro do STF indicado pelo tribunal, (ii) Ministro do
Superior Tribunal de Justiça (STJ) indicado pelo STJ, que será corregedor de justiça; (iii) Ministro do Tribunal Superior do Trabalho (TST) indicado pelo tribunal; (iv) Desembargador de 
Segundo Streck, Sarlet e Clève (2005, p. 22-23) o poder regulamentar do $\mathrm{CNJ}$ não pode: (i) estabelecer novos direitos e deveres; (ii) criar regras gerais e abstratas e (iii) restringir direitos fundamentais. Esse poder regulamentar, por outro lado, deveria concretizar leis formais já estabelecidas, por meio de uma função parecida com as leis medidas, no âmbito de sua competência (atuações financeiras e orçamentárias, cumprimento dos deveres judiciais e outras competências postas na constituição e no Estatuto da Magistratura). Excepcionalmente, esse poder regulamentar poderia concretizar diretamente a Constituição Federal de 1988. Há, contudo, uma diferença estrutural e política entre as leis ordinárias e complementares, de um lado, e o poder regulamentar do CNJ. A maneira como essa separação será feita depende de duas questões: (i) novo Estatuto da Magistratura Nacional e (ii) costumes constitucionais firmados pelo CNJ, STF, Congresso Nacional e Presidência da República.

Novamente essa competência (fiscalizar legalidade, impessoalidade, moralidade, publicidade e eficiência) possui principalmente função de accountability horizontal, já que o CNJ (agente estatal) fiscaliza a concretização de valores da administração pública. Por sua vez, a concretização desses princípios, como a publicidade, permite a realização de accountability social (vertical não eleitoral) sobre magistrados e serviços auxiliares, sendo aplicadas as sanções de exposição pública ou de denúncias às ouvidorias. Esses são importantes mecanismos para transformar em accountable os agentes estatais, analisados não na prestação da jurisdição, e sim das atividades administrativas, financeiras e na apresentação dos dados referentes à prestação da jurisdição (informações sobre os processos, a quantidade de processos analisados, etc.).

Sobre o princípio da publicidade, observam importantes mudanças implantadas pelo $\mathrm{CNJ}$ na efetivação dessa competência. Foram estabelecidas e concretizadas diversas resoluções para trazer maior publicidade, no poder Judiciário. Essas informações são obtidas pelo poder de accountability horizontal,

um dos Tribunais de Justiça (TJ) indicado pelo STF; (v) Juiz estadual indicado pelo STJ; (vi) Juiz do Tribunal Regional Federal (TRF) indicado pelo STJ; (vii) Juiz federal indicado pelo STJ; (viii) Juiz de um Tribunal Regional do Trabalho indicado pelo TST; (ix) Juiz do trabalho indicado pelo TST; $(x)$ membro do Ministério Público da União indicado pelo Procurador Geral da República; (xi) membro do Ministério Público estadual, escolhido pelo Procurador Geral da República e indicado pelos ministérios públicos estaduais; (xii) dois advogados indicados pelo Conselho Federal da OAB; (xiii) dois cidadãos de notável saber jurídico e moral ilibada, sendo um que permite ao CNJ exigir a apresentação desses dados. Por outro lado, a publicação dessas informações permite ao povo, mandante dos agentes estatais eleitos ou não eleitos, e a grupos da sociedade civil exercerem a accountability social sobre o poder Judiciário.

Com mais informações sobre orçamento, quantidade de processos apresentados e julgados, estrutura administrava e tantos outros dados fornecidos pelo $\mathrm{CNJ}$, a população e grupos da sociedade civil podem discutir a atuação do poder Judiciário questionando se a independência judicial institucional está sendo bem utilizada para prestar uma jurisdição adequada e célere aos cidadãos, assim como possibilita analisar importantes elementos de accountability comportamental judicial. Como o objetivo do CNJ é ampliar a accountability judicial institucional, não faz sentido retirar o poder de controle externo exercido pelo poder Legislativo com o auxílio dos tribunais de conta. Além disso, os cidadãos detêm a faculdade de denunciar os ilícitos praticados por magistrados e serviços judiciais auxiliares, um mecanismo de accountability vertical não eleitoral, que permite a aplicação de sanção por órgão de accountability horizontal (CNJ) sobre agentes estatais não eleitos (magistrados, servidores auxiliares e pessoas que agem por delegação).

A análise da infração disciplinar não prejudica o exercício do poder correcional e disciplinar pelos tribunais e por suas corregedorias. Esse mecanismo estabelece a competência disciplinar administrativa concorrente, podendo tanto o $\mathrm{CNJ}$ como os tribunais

indicado pela câmara dos deputados e outro pelo Senado federal. A EC 61/09 alterou o art. 103-B, I, CF, prescrevendo que o Presidente do STF seria membro do CNJ e presidente desse conselho.

37 Como a maior parte do CNJ é composta por juízes e a participação dos cidadãos é pequena, Bercovici (2005, p. 190) afirma que: "toda a polêmica gerada sobre o 'controle externo' do Poder Judiciário não faz nenhum sentido. O controle destas instituições é perfeitamente adequado a um Estado Constitucional fundado na soberania popular e, no nosso caso, não foi criado nenhum controle externo real".

38 Diminuiu, mas não eliminou a crítica à criação do CNJ. Por exemplo, a Associação dos Magistrados do Brasil (AMB) propôs ADI 3367/DF, que pleiteava a declaração da inconstitucionalidade do CNJ. A ação foi julgada improcedente. Sobre a alegada inconstitucionalidade do CNJ, parte da doutrina e a jurisprudência afirmam que inexiste afronta ao princípio federativo em virtude do caráter nacional da magistratura. Sampaio (2007, p. 254) defende a existência da unidade do poder Judiciário, sendo esse poder nacional. Por sua vez, o ministro relator da ADI 3367/DF afirma que a jurisdição, exercida pelo poder Judiciário, manifesta a unidade do poder soberano do Estado. Sendo assim, a jurisdição, por conseqüência o poder Judiciário, é una, indivisível e nacional (BRASIL, 2005, 
fiscalizarem administrativamente magistrados, servidores auxiliares e prestadores de serviços públicos delegados. Esse desenho institucional aumenta a accountability judicial comportamental ao permitir que mais de um órgão faça o julgamento das infrações disciplinares ${ }^{39}$.

Como o CNJ possui funções e competências de accountability judicial interna, nada mais adequado do que o CNJ representar ao Ministério Público, agente de accountability horizontal externa dos poderes constituídos, nos casos de ocorrência de crimes. Nesse sentido, o CNJ deve formular um relatório anual, sugerindo providências que julgar pertinentes, sobre o contexto e a situação do poder Judiciário. Esse relatório deve integrar a mensagem remetida pelo Presidente do STF ao Congresso Nacional para a abertura da sessão legislativa. Para auxiliar a presidência do CNJ na elaboração desse relatório, foi constituído o Departamento de Pesquisas Judiciárias (DPJ), órgão de assessoramento técnico. Conforme visto no contexto de criação dos conselhos de justiça na América Latina, por Hammergren (2002), faltavam conhecimentos técnicos sobre administração, gerenciamento e capacidade para fazer diagnósticos do poder Judiciário pela cúpula diretiva dos tribunais. Além disso, a apresentação de informações do poder Judiciário para o público externo é importante para permitir a accountability horizontal do poder Judiciário pelos outros poderes e ministério público e a accountability social pela sociedade civil.

A Lei n. 12106 de 2009, por sua vez, disciplinou o Departamento de Monitoramento e Fiscalização do Sistema Carcerário e do Sistema de Execução de Medidas Socioeducativas (DMF). Através do DMF o CNJ realiza a accountability horizontal sobre os agentes estatais que atuam nos referidos sistemas.

Por fim, nos termos do art. 103-B, $\S 7^{\circ}, \mathrm{CF}$, há determinação da criação de ouvidorias de justiça nos estados para o recebimento de denúncias contra magistrados e servidores auxiliares. A Resolução n. 103 de 2010 regulamenta esse dispositivo constitucio-

p. 243-244). Ainda sobre isso, segundo Clève (2011b, p. 87), a jurisdição é una, pois uma ação apresentada receberá uma única resposta final dentro do Estado de Direito brasileiro, porém existem duas justiças que prestam a jurisdição no Estado brasileiro.

$39 \mathrm{O}$ art. $103, \S 4^{\circ}$, III e V, CF, estabelece nítida competência administrativa disciplinar entre o $\mathrm{CNJ}$ e o tribunal que pertence o magistrado. Desse modo, o CNJ pode originalmente analisar um ilícito disciplinar, além de avocar e rever processos disciplinares iniciados nos tribunais. Desse modo, o STF, na ADI 4638, proposta pela AMB, declarou a constitucionalidade da competência disciplinar concorrente. nal, disciplinando a ouvidoria do $\mathrm{CNJ}$ e a criação de ouvidorias nos tribunais. A ouvidoria do $\mathrm{CNJ}$ constituise em canal de direto entre o cidadão e o $\mathrm{CNJ}$, buscando que as informações trazidas pelos cidadãos orientem e aprimorem a atuação do conselho, de acordo com o art. $2^{\circ}$ da Resolução n. 103. Há nesse dispositivo a construção de um desenho institucional que permite aos jurisdicionados apresentarem informações e pleitos que melhoram a atuação do CNJ. Assim, os cidadãos influenciam os agentes estatais não eleitos por meio de accountability vertical não eleitoral em tema institucional. Metade das demandas feita às ouvidorias versa sobre reclamações sobre magistrados e serviços auxiliares. Destas, $50 \%$ trata da morosidade judicial (FREIRE, BERNARDES \& ROVER, 2001, p. 92-94). Em outras palavras, $25 \%$ de todas as demandas da ouvidoria enfrentam a questão da morosidade. Esse dado afirma que os cidadãos utilizam-se da apresentação de demandas às ouvidorias (accountability vertical não eleitoral) para reivindicar um elemento da accountability judicial comportamental (eficiência).

\section{CONCLUSÕES}

A independência judicial institucional constitui-se na autonomia que o poder Judiciário possui para realizar adequadamente sua função fim: exercer a jurisdição. São diversos os elementos que compõem a independência judicial institucional, como: seleção dos magistrados e de servidores auxiliares, exercício do poder disciplinar sobre magistrados e servidores auxiliares, autonomias (administrativa, financeira e orçamentária), garantias funcionais (vitaliciedade, irredutibilidade de salários e inamovibilidade), possibilidade de participar do processo legislativo de atos normativos relevantes para a magistratura e para a gestão da justiça, etc. A accountability judicial institucional diz respeito ao poder de fiscalizar, influenciar e sancionar o poder Judiciário como um poder, como uma instituição.

A essência dos Estados Democráticos de Direito constitui-se no modelo de separação dos poderes com pesos e contrapesos. Desse modo não existe e não é adequado que ocorra uma independência judicial institucional plena, sem o exercício de accountability judicial institucional por outros poderes e por outros agentes estatais. Nesse sentido, por exemplo, é legítimo que o poder Executivo e o poder Legislativo participem da aprovação do Estatuto da Magistratura, do orçamento do poder Judiciário e das normas processuais. A configuração específica da independência judicial institucional em cada país depende do desenho constitucional da separação dos poderes, das relações de pesos e contrapesos e dos costumes constitucionais firmados pelos agentes 
estatais na interpretação e na concretização da constituição. Mudanças nos costumes constitucionais são possíveis, mas impõem forte carga argumentativa ao agente estatal que busca alterar esse costume.

Como o poder Judiciário é composto por diversos agentes estatais (magistrados, órgãos e tribunais), a accountability judicial institucional também é exercida por alguns agentes do poder Judiciário sobre outros agentes judiciais. Em outras palavras, além da accountability judicial institucional externa, há a accountability judicial institucional interna. Essa forma de accountability é exercida pelo tribunal de maior hierarquia, pelos conselhos de justiça (quando a maioria dos membros são juízes), pela direção dos tribunais e pela Corregedoria de Justiça. Observa-se uma tendência, nos Estados Democráticos, em aumentar a accountability judicial institucional interna e diminuir a accountability judicial institucional externa. A ampliação da accountability judicial institucional interna não afronta a independência judicial apesar de redesenhar as relações de poder dentro do poder Judiciário.

O poder Judiciário brasileiro é dotado de grande independência judicial institucional e plena independência judicial decisional. No que se refere ao poder disciplinar administrativo, competia apenas aos próprios tribunais fiscalizarem os deveres judiciais dos magistrados após a Constituição Federal de 1988. Desse modo, não se desenhou adequadamente o sistema de controle disciplinar administrativo dos juízes, pois não foram concedidos os incentivos suficientes para que os magistrados buscassem seguir da melhor maneira possível os deveres funcionais.

Com a preocupação de atacar o problema da prestação da justiça adequada (garantia dos direitos) e célere e o déficit de accountabilities judiciais, foi proposta a PEC 96/92 e a PEC 112/95. A reforma do poder Judiciário (EC 45/2004) procurou atacar o problema da eficiência judicial, além de aumentar os instrumentos de accountability dos agentes estatais e de accountability judiciais institucional e comportamental.

O CNJ constitui-se em órgão do poder Judiciário, composto predominantemente de magistrados, com poderes de accountabilities judiciais. Desse modo, o CNJ é um agente estatal de accountability judicial institucional interno. A atuação do CNJ promove principalmente um redesenho parcial das relações de poder administrativo, disciplinar, orçamentário e financeiro no seio do poder Judiciário, retirando poder principalmente das direções dos tribunais. As competências do CNJ promovem principalmente a accountability horizontal, pois o conselho exige informações e justificações dos magistrados, tribunais, servidores auxiliares, cartórios e notários, podendo sancioná-los. Por outro lado, por meio da concretização do princípio da publicidade no poder Judiciário, do recebimento de denúncias de ilícitos disciplinares de agentes judiciais, da existência de ouvidorias de justiça e da apresentação de relatórios, o CNJ possibilita o exercício de accountabilities sociais no poder Judiciário.

Fabrício Ricardo de Limas Tomio (fabricio.tomio@pq.cnpq.br) é Doutor em Ciência Politica pela Universidade Estadual de Campinas (Unicamp) e Professor do Departamento de Direito Público da Universidade Federal do Paraná (UFPR).

Ilton Norberto Robl Filho (norbertorobl@gmail.com) é Doutor em Direito pela Universidade Federal do Paraná (UFPR) e Professor do Curso de Direito da Universidade de Passo Fundo".

\section{REFERÊNCIAS BIBLIOGRÁFICAS}

ARATO, A. 2002. Representação, soberania popular e accountability. Lua Nova, São Paulo, n. 55-56, p. 85-103. Disponível em: http://www.scielo.br/ $\mathrm{pdf} / \mathrm{ln} / \mathrm{n} 55-56 / \mathrm{a} 04 \mathrm{n} 5556 . \mathrm{pdf}$. Acesso em: 10.abr.2013.

BERCOVICI, G. 2005. Controle externo do poder Judiciário e a soberania popular. In: TAVARES, A. R.; LENZA, P. \& ALARCÓN, P. J. L. (orgs.). Reforma do poder Judiciário: analisada e comentada. São Paulo: Método.
BRODY, D. C. 2008. The Use of Judicial Performance Evaluation to Enhance Judicial Accountability, Judicial Independence and Public Trust. Denver University Law Review, Denver, v. 86, n. 1, p. 1-42.

CAMPOS, A. M. 1990. Accountability: quando poderemos traduzir para o português? Revista de Administração Pública, Rio de Janeiro, v. 24, n. 2, p. 30-50, fev.-abr. Disponível em: http://material. canaldosconcursos.com.br/pdf/auditor_fiscal_ 
da_receita_federal_administracao_publica/ administracao_publica_wagner_rabello_aula_07 parte_02.pdf. Acesso em: 10.abr.2013.

CARRINGTON, P. D. 1998. Judicial Independence and Democratic Accountability in Highest State Courts. Law and contemporary problems, Durham, v. 61, n. 3, p. 79-126, Summer.

CLÈVE, C. M. 2011a. Poder Judiciário: autonomia e justiça. In: CLÈVE, C. M. \& BARROSO, L. R. (orgs.). Doutrinas essenciais de Direito Constitucional. V. 4. São Paulo: RT.

2011b. Atividade legislativa do poder Executivo. $3^{\mathrm{a}}$ ed. São Paulo: RT.

DIAMOND, L.; PLATTNER, M. F. \& SCHEDLER, A. 1999. The Self-Restraining State: Power and accountability in new democracies. Boulder: Lynne Rienner.

FEREJOHN, J. 1999. Independent Judges, Dependent Judiciary: Explaining judicial independence. Southern California Law Review, Los Angeles, v. 72, p. 353384. Disponível em: http://www-bcf.usc.edu/ $\sim$ usclrev/pdf/072303.pdf. Acesso em: 10.abr.2013.

2002. Judicializing Politics, Politicizing Law. Law and Contemporary Problems, Durham, v. 65, n. 3, p. 41-69.

FREIRE, G. M. C. A.; BERNARDES, M. B. \& ROVER, A. J. 2011. Políticas públicas responsivas do Conselho Nacional de Justiça: análise da ouvidoria. Revista Democracia Digital e Governo Eletrônico, Florianópolis, n. 5, p. 84-99.

GAROUPA, N. \& GINSBURG, T. 2008. Guarding the Guardians: judicial councils and judicial independence. American Journal of Comparative Law, Working Paper, p. 1-43. Disponível em: http:/ $/ \mathrm{p}$ a $\mathrm{p}$ e $\mathrm{r} \mathrm{s}$. $\mathrm{s} \mathrm{s} \mathrm{r} \mathrm{n}$. c o m / s o $13 /$ papers.cfm?abstract_id=1303847. Acesso em: 10.abr.2013.

GEYH, C. 2003. Judicial Independence, Judicial Accountability, and the Role of Constitutional Norms in Congressional Regulation of the Courts. Indiana Law Journal, Bloomington, v. 78, n. 153, p. 153-222.

HAMMERGREN, L. 2002. Do Judicial Councils Further Judicial Reform? Lessons from Latin America. Washington (DC): Carnegie Endowment for International Peace.

MANIN, B.; PRZEWORSKI, A. \& STOKES, S. C. 2006. Eleições e representação. Lua Nova, São Paulo, n. 67, p. 105-138. Disponível em: http:// www.scielo.br/pdf/ln/n67/a05n67.pdf. Acesso em: 10.abr.2013.

MIGUEL, L. F. 2005. Impasses da Accountability: dilemas e alternativas da representação política. Revista de Sociologia e Política, Curitiba, n. 25, p. 25-38, nov. Disponível em: http://www.scielo. br/pdf/rsocp/n25/31109.pdf. Acesso em: 10.abr.2013.

MOTA, A. C. Y. H. A. 2006. Accountability no Brasil: os cidadãos e os meios institucionais de controle dos seus representantes. São Paulo. Tese (Doutorado em Ciência Política). Universidade de São Paulo.

NORTH, D. 1995. The New Institutional Economics and Third World Development. In: HARRIS, J.; HUNTER, J. \& LEWIS, C. M. (eds.). The New Institutional Economics and Third World Development. London: Routledge.

OFFE, C. 1999. How Can We Trust Our Fellow Citizens? In: WARREN, M. E. (ed.). Democracy and Trust. Cambridge (UK): Cambridge University.

O’DONNELL, G. 1998. Accountability Horizontal e novas poliarquias. Lua Nova, São Paulo, n. 44, p. 27-54. Disponível em: http://www.scielo.br/pdf/ ln/n44/a03n44. Acesso em: 10.abr.2013.

2009. Democracia Delegativa. Journal of Democracy en Español, Santiago, v. 5, n. 1, p. 723, jul. Disponível em: http:// www.plataformademocratica.org/Publicacoes/ 11566.pdf. Acesso em: 10.abr.2013.

PINHO, J. A. G. \& SACRAMENTO, A. R. S. 2009. Accountability: já podemos traduzi-la para o português? Revista de Administração Pública, Rio de Janeiro, v. 43, n. 6, p. 1343-1368.

PERUZZOTTI, E. \& SMULOVITZ, C. 2002. Accountability social: la outra cara del control. In: Controlando la política. Ciudadanos e medios en las nuevas democracias latinoamericanas. Buenos Aires: Temas.

PRZEWORSKI, A. 1999. O Estado e o cidadão. In: PEREIRA, L. C. B.; WILHEIM, J. \& SOLA, L. (orgs.). Sociedade e Estado em transformação. São Paulo: UNESP.

2006. Sobre o desenho do Estado: uma perspectiva agent $\mathrm{x}$ mandante. In: PEREIRA, L. C. B. \& SPINK, P. (orgs.). Reforma do Estado e administração pública gerencial. $7^{\mathrm{a}}$ ed. Rio de Janeiro: FGV.

ROMÊO, C. I. M. 2009. Mecanismos institucionais de controle e limitação do poder. In: FERREIRA, 
L. P.; GUANABARA, R. \& JORGE, V. L. (orgs.). Curso de Teoria Geral do Estado. Rio de Janeiro: Elsevier.

ROSE-ACKERMAN, S. 2005. Rendición de cuentas e Estado de derecho en las consolidaciones de las democracias. Perfiles Latinoamericanos, Ciudad del Mexico, n. 26, p. 9-53, jul.-dic.

SADEK, M. T. O poder Judiciário na reforma do Estado. In: PEREIRA, L. C. B.; WILHEIM, J. \& SOLA, L. (orgs.). Sociedade e Estado em transformação. São Paulo: UNESP.

. 2004. Judiciário: mudanças e reformas. Estudos avançados, São Paulo, v. 18, n. 51, p. 91-92, maioago.

SAMPAIO, J. A. L. 2007. O Conselho Nacional de Justiça e a independência do poder Judiciário. Belo Horizonte: Del Rey.

SCHEDLER, A. 1999. Conceptualizing accountability.
In: DIAMOND, L.; PLATTNER, M. F. \& SCHEDLER, A. (eds.). The Self-Restraining State: power and accountability in new democracies. Colorado: Lynne Rienner.

STRECK, L. L.; SARLET, I. W. \& CLÈVE, C. M. Os limites constitucionais das resoluções do Conselho Nacional de Justiça (CNJ) e Conselho Nacional do Ministério Público (CNMP). Revista da ESMESC, Florianópolis, v. 12, n. 18, p. 15-24.

Disponível em: www.esmesc.com.br/upload/arquivos/ 1-1246645274.PDF. Acesso em: 10.abr.2013.

TREBILCOCK, M. J. \& DANIELS, R. J. 2008. Rule of Law Reform and Development: Charting the fragile path of progress. Cheltenham: Edward Elgar.

ZEMANS, F. K. 1999. The Accountable Judge: Guardian of judicial independence. Southern California Law Review, Los Angeles, v. 72, p. 625655, Jan-Mar.

\section{OUTRAS FONTES}

BRASIL. 1988. Constituição da República Federativa do Brasil de 1988. Brasília.

1992a. Projeto de Emenda à Constituição n. 96 de 1992. Diário do Congresso Nacional, Brasília, Seção 1, p. 7847-7853, 1.maio. 1992b. Redação Final do Projeto de Emenda à Constituição n. 96 de 1992. Diário do Congresso Nacional, Brasília, p. 30903-30915, 8.jun.

1995. Projeto de Emenda à Constituição n. 112 de 1995. Diário do Congresso Nacional, Brasília, Seção 1, p. 16486-16487, 8.ago. 